\title{
Preparation and Effect of Different Temperature and Time on Nutritional Quality of Tomato Paste
}

\author{
Sweta Singh, Baljor Singh, Ajay Kumar Singh, Kunal Singh* and Vinay Kumar Pandey \\ Department of Food Process Engineering Vaugh Institute of Agriculture Engineering and \\ Technology, SHUATS, Allahabad, India \\ *Corresponding author
}

\begin{tabular}{|c|c|}
\hline \multicolumn{2}{|r|}{ A B S T R A C T } \\
\hline Keywords & \multirow{4}{*}{$\begin{array}{l}\text { Tomato is a che fly available vegetable in India and several techniques are available in the } \\
\text { market for processing of tomato. However, in this study we have tried to investigate cost } \\
\text { effective procedure for preparation of tomato paste by using vacuum drying. Tomato paste } \\
\text { was prepared and its sensory evaluation exposed that the prepared tomato paste by same } \\
\text { procedure was acceptable for consumption. Determination of content of lycopene, beta- } \\
\text { carotene, ascorbic acid, acidity and TSS revealed that } 5^{\circ} \mathrm{C} \text { and } 25^{\circ} \mathrm{C} \text { temperatures were } \\
\text { suitable for long time storage of paste while } 50^{\circ} \mathrm{C}, 75^{\circ} \mathrm{C} \text { and } 100^{\circ} \mathrm{C} \text { temperatures were not } \\
\text { suitable for long time storage of paste. During storage time the content of lycopene, beta- } \\
\text { carotene and ascorbic acid was found to be declining while percent acidity was found to be } \\
\text { increasing with increasing temperature more than } 25^{\circ} \mathrm{C} \text {. Similarly, TSS of paste was found } \\
\text { to be declining with increasing temperature. In conclusion investigated vacuum drying } \\
\text { procedure for tomato paste preparation could be used for commercial value. }\end{array}$} \\
\hline $\begin{array}{l}\text { Tomato paste, } \\
\text { Vacuum dryer, } \\
\text { Lycopene, } \\
\text { Beta-carotene, } \\
\text { Ascorbic acid }\end{array}$ & \\
\hline Article Info & \\
\hline $\begin{array}{l}\text { Accepted: } \\
\text { 10 October } 2020 \\
\text { Available Online: } \\
10 \text { November } 2020\end{array}$ & \\
\hline
\end{tabular}

\section{Introduction}

Fruits and vegetables are used over world for consumption due to their nutritional value and cheap available ${ }^{[1]}$. In recent years constantly increase in production of fruits and vegetables. Therefore, fruits and vegetables could be used for processing and preparation of value added products. In addition, fruits by-products not only good source of bioactive compounds but also could be used as various value-added products ${ }^{[2]}$.Typically, fruits are processed into juice, beverage, squash and syrups ${ }^{[3]}$.Tomato (Lycopersicon esculentum Mill.) is the most important agricultural product among fresh vegetables in most countries. Tomato belongs to the Solanaceae family. Tomatoes have become more popular in recent years due to value added properties. As it is a relatively short duration crop and gives a high yield, it is economically attractive and the area under cultivation is increasing daily.

Tomato is an essential vegetable of human diet. It is a good nutritional resource rich in vitamin $\mathrm{C}$ and other important constituents such as carotenes, lycopene, phenolics and organic acids. Also, tomatoes contain important metabolites such as tocopherol, 
lutein, and folate, which contribute to their beneficial effects ${ }^{[4,5,6]}$. In recent years the phytochemicals from natural resources such as vegetables, fruits, oilseeds and herbs gained therapeutic importance due to functional properties ${ }^{[7]}$. Intake of betacarotene and lycopene, in food is related to lower the incidence of cardiovascular disease, prostate, gastrointestinal and epithelial cell cancers $^{[8,9,10]}$.

Furthermore, tomato possesses proteins, carbohydrates, fats and minerals. In India, lots of tomatoes are wasted due to lack of proper processing and preservation technique. During the top season tomatoes are sold at low prices due to more supply, resulting in less return to growers. But in off peak season tomatoes availability is so poor and price is so high which is unreachable to consumer. Tomatoes may be processed to give tomato juice and concentrated tomato juice, puree and paste. Tomato puree and paste may be marketed directly to the consumer or it may be an ingredient in other products, for example, tomato ketchup, soup, and sauces [11]. Drying is one of the oldest methods for the preservation of food products ${ }^{[12]}$. Many reports for the processing of tomato have been documented in literatures, such as canning ${ }^{[13]}$, use of sun drying ${ }^{[14]}$. Several studies have been described the use of chemical preservatives such as sodium benzoate ${ }^{[15]}$, and sodium Meta bisulfite ${ }^{[16]}$, for preparation of tomato juice, paste and so on. Hossain ${ }^{[17]}$, found sodium benzoate had better additive as compared potassium metabi-sulfite and sorbic acid for preservation of tomato juice. It has been found lower temperature $\left(4^{\circ} \mathrm{C} \&-10^{\circ} \mathrm{C}\right)$ has more capable for retention of quality of tomato paste than higher temperature (20$\left.40^{\circ} \mathrm{C}\right)^{[15]}$. However, limited studies have been done in regarding of tomato processing and preservation of its products. Nowadays, with the spread of education, change in habits, growth in working women, the demand for processed vegetables/fruits is increasing progressively.

So that tomato processed food could be used as safe and nutritious products throughout country. Therefore, the main objective of this study was to investigate the simple and cost effective process of preparation of tomato paste which have nutritional quality and suitable for ready to use. In the view of this in this study we took an effort to develop simple procedure for preparation of tomato paste. Also, storage of tomato paste with different temperature and time has been studied by the determination of lycopene, TSS, betacarotene and ascorbic acid.

\section{Materials and Methods}

\section{Preparation of tomato paste}

Fully riped tomatoes with uniform in size and colour were procured from the department of horticulture, Allahabad SHUAT University (UP) India. Collected tomatoes (3kg) were thoroughly washed by water and blanched at $95^{\circ} \mathrm{C}$ for $5 \mathrm{~min}$ for further processes. The tomatoes were sliced by knife into small pieces with uniform size. All pieces were crushed into pulp by grinder and mixer. The pulp of tomatoes was allowed for formation of paste by using vacuum drier. The prepared pastes were preserved in a glass bottle by the addition of sodium benzoate.

\section{Determination of lycopene content}

The amount of lycopene contents in tomato and prepared pastes were measured by using the method of Grolier ${ }^{[18]}$. The sample (1-2 g) was extracted with acetone in a pestle and mortar. Thereafter, the acetone extract was kept in a separating funnel containing with 10 to $15 \mathrm{ml}$ of petroleum ether and mixed gently. The colour pigment was extracted with petroleum ether from acetone extract. This 
process was continued until it became colourless. The color phase was transferred to a volumetric flask and measured the absorbance at $503 \mathrm{~nm}$ by Spectrophotometer. Lycopene content was calculated by the following formula:

$\mathrm{mg}$ of lycopene per 100

$(3.1206 \times$ O.D. of sample $X$ volume made up $X$ Dilution $\times 100)$ $(1 \times W t$. of sample $\times 100)$

\section{Determination of Total Soluble Solid (TSS)}

Total soluble solids (TSS) content of all samples were determined by using a digital and were expressed as degrees ${ }^{\circ}$ Brix according to the AOAC (2002). All the readings were performed at $30^{\circ} \mathrm{C}$ after filtration through hydrophilic cotton.

\section{Determination of Beta-Carotene content}

Beta-carotene available in all samples was determined by using the method of Srivastava and Kumar ${ }^{[19]}$ with slight modifications. Two grams of sample was extracted with $10-15 \mathrm{ml}$ acetone with the adding of few crystal of anhydrous sodium sulfite. The residue was reextracted until colourless. The solution was transferred into a separating funnel and washed with 10-15 ml petroleum ether. The lower phase was discarded and collected upper layer in a volumetric flask. After that volume was made $100 \mathrm{ml}$ with petroleum ether and recorded absorbance at 452nm. $\beta$ carotene was calculated using the following equation:

Beta - Carotene $(\mu \mathrm{g} \mid 100 \mathrm{~g})=\frac{0 . \mathrm{D} . \times 13.9 \times 100}{\text { Wt. of sample } \times 560 \times 1000}$

\section{Determination of Ascorbic Acid Content}

Ascorbic acid was estimated by using the method of Ranganna ${ }^{[20]}$ with some modification. The extract was prepared with using $3 \% \quad \mathrm{HPO}_{3}$ at room temperature. The extract was filtered through the glass wool in a flask. Thereafter, $10 \mathrm{ml}$ of aliquot was titrated against dye solution till pink colour formation. Ascorbic acid content of the sample was calculated by following formula.

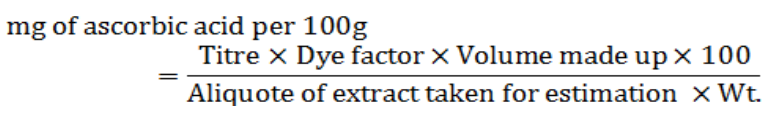

\section{Determination of Titratable Acidity}

The samples were extracted in distilled water. The extracted sample was titrated against adding $0.1 \mathrm{NNaOH}$ until a $\mathrm{pH}$ of 8.1 was attained. The volume of the sodium hydroxide, used for titration, was multiplied by a correction factor of 0.064 to estimate titratable acidity as percentage of citric acid monohydrate (g $100 \mathrm{~g}$-1) according to the AOAC (2002).

\section{Results and Discussion}

\section{Tomato paste preparation}

The aim this study was the development of simple method for preparation of tomato paste.

We took an effort for development of method with using heating by using using vacuum drier. The prepared tomato paste was ready to use and its appearance and flavor were acceptable. The sensory evaluation was quite similar to the earlier reported study ${ }^{[15]}$. Also, preservation study of tomato paste was conducted with using different temperature and time period.

\section{Determination of lycopene content}

Lycopene content in tomato paste was estimated with different temperature and time period. The lycopene content was found to be constant at $5^{\circ} \mathrm{C}$ and $25^{\circ} \mathrm{Ctemperature} \mathrm{up} \mathrm{to} \mathrm{the}$ period of 60 days of preservation but, slightly declining of lycopene content was observed at 
$50^{\circ} \mathrm{C}$ temperature up to the period of 20 days. Prominently decreasing in level of lycopene content was observed from the period of 10 60 days (Table 1). This result was similar to earlier reported study of Hossain ${ }^{[11]}$. Lycopene content was decreased during storage period for all samples. However, ambient temperature $\left(25^{\circ} \mathrm{C}\right)$ retained lycopene content short time. The loss of lycopene at all conditions might be due to oxidation which depends on temperature and moisture ${ }^{[21]}$.

Table.1 Determination of lycopene content $(\mathrm{mg} / \mathrm{g})$ in tomato paste with different temperature and time periods

\begin{tabular}{|l|l|l|l|l|l|l|l|}
\hline Temp & 1Day & 10Days & 20days & 30Days & 40Days & 50Days & 60Days \\
\hline $\mathbf{5}^{\mathbf{0}} \mathbf{C}$ & 13 & 12.8 & 13.2 & 13.1 & 12.7 & 12.9 & 13.2 \\
\hline $\mathbf{2 5} \mathbf{C}$ & 12.9 & 13.2 & 12.8 & 12.9 & 13.2 & 13.1 & 12.5 \\
\hline $\mathbf{5 0}^{\mathbf{0}} \mathbf{C}$ & 13.1 & 12.8 & 10.8 & 9.4 & 8.3 & 6.7 & 6.4 \\
\hline $\mathbf{7 5}^{\mathbf{0}} \mathbf{C}$ & 12.5 & 11.8 & 9.8 & 9.2 & 7.2 & 6.1 & 3.3 \\
\hline $\mathbf{1 0 0}^{\mathbf{0}} \mathbf{C}$ & 12.3 & 10.5 & 7.02 & 6.3 & 5.2 & 2.2 & 2.4 \\
\hline
\end{tabular}

Table.2 Determination of TSS in tomato paste with different temperature and time periods

\begin{tabular}{|c|c|c|c|c|c|c|c|}
\hline Temp & 1Day & 10Days & 20Days & 30Days & 40Days & 50Days & 60Days \\
\hline $\mathbf{5}^{\mathbf{C}} \mathbf{C}$ & 4.5 & 4.4 & 4.3 & 4.5 & 4.2 & 4.2 & 4.4 \\
\hline $\mathbf{2 5}^{\mathbf{0}} \mathbf{C}$ & 4.4 & 4.3 & 4.2 & 4.3 & 4.2 & 4.1 & 4.2 \\
\hline $\mathbf{5 0}^{\mathbf{0}} \mathbf{C}$ & 4.5 & 4.4 & 4.4 & 4.5 & 4.1 & 4.2 & 4.1 \\
\hline $\mathbf{7 5}^{\mathbf{0}} \mathbf{C}$ & 4.3 & 4.3 & 4.0 & 3.8 & 3.5 & 3.6 & 3.5 \\
\hline $\mathbf{1 0 0}^{\mathbf{0}} \mathbf{C}$ & 4.2 & 4.1 & 3.7 & 3.2 & 3.2 & 3.1 & 2.9 \\
\hline
\end{tabular}

Table.3 Determination of beta-carotene content $(\mu \mathrm{g} / 100 \mathrm{~g})$ in tomato paste with different temperature and time periods

\begin{tabular}{|l|l|l|l|l|l|l|l|}
\hline Temp & 1Day & 10Days & 20Days & 30Days & 40Days & 50Days & 60Days \\
\hline $\mathbf{5}^{\mathbf{}} \mathbf{C}$ & 110 & 109 & 110 & 111 & 112 & 113 & 112 \\
\hline $\mathbf{2 5}^{\mathbf{0}} \mathbf{C}$ & 108 & 112 & 113 & 112 & 113 & 110 & 110 \\
\hline $\mathbf{5 0}^{\mathbf{0}} \mathbf{C}$ & 108 & 113 & 105 & 104 & 101 & 97.34 & 80.5 \\
\hline $\mathbf{7 5}^{\mathbf{C}} \mathbf{C}$ & 111 & 109 & 98.78 & 90.35 & 84.10 & 70.34 & 70.86 \\
\hline $\mathbf{1 0 0}^{\mathbf{0}} \mathbf{C}$ & 110 & 105 & 95.67 & 84.76 & 80.54 & 60.2 & 60.6 \\
\hline
\end{tabular}

Table.4 Determination of ascorbic acid content $(\mathrm{mg} / 100 \mathrm{~g})$ in tomato paste with different temperature and time periods

\begin{tabular}{|c|c|c|c|c|c|c|c|}
\hline Temp & 1Day & 10Days & 20Days & 30Days & 40Days & 50Days & 60Days \\
\hline $\mathbf{5}^{\mathbf{0}} \mathbf{C}$ & 17 & 17 & 17 & 17 & 18 & 16 & 17 \\
\hline $\mathbf{2 5}^{\mathbf{0}} \mathbf{C}$ & 18 & 17 & 18 & 16 & 17 & 18 & 16 \\
\hline $\mathbf{5 0}^{\mathbf{0}} \mathbf{C}$ & 16 & 16 & 14 & 12 & 11 & 10 & 8 \\
\hline $\mathbf{7 5}^{\mathbf{0}} \mathbf{C}$ & 15 & 14 & 12 & 10 & 8 & 6 & 5 \\
\hline $\mathbf{1 0 0}^{\mathbf{0}} \mathbf{C}$ & 15 & 14 & 11 & 9 & 7 & 5 & 6 \\
\hline
\end{tabular}


Table.5 Determination of titratable acidity (\%) in tomato paste with different temperature and time periods

\begin{tabular}{|c|c|c|c|c|c|c|c|}
\hline Temp & 1Day & 10Days & 20Days & 30Days & 40Days & 50Days & 60Days \\
\hline $\mathbf{5}^{\mathbf{C}} \mathbf{C}$ & 0.10 & 0.09 & 0.11 & 0.11 & 0.13 & 0.09 & 0.11 \\
\hline $\mathbf{2 5}^{\mathbf{0}} \mathbf{C}$ & 0.11 & 0.10 & 0.12 & 0.11 & 0.12 & 0.12 & 0.13 \\
\hline $\mathbf{5 0}^{\mathbf{0}} \mathbf{C}$ & 0.13 & 0.13 & 0.14 & 0.15 & 0.17 & 0.17 & 0.18 \\
\hline $\mathbf{7 5}^{\mathbf{0}} \mathbf{C}$ & 0.15 & 0.15 & 0.16 & 0.19 & 0.20 & 0.20 & 0.21 \\
\hline $\mathbf{1 0 0}^{\mathbf{0}} \mathbf{C}$ & 0.15 & 0.17 & 0.21 & 0.23 & 0.24 & 0.25 & 0.25 \\
\hline
\end{tabular}

\section{Determination of Total Soluble Solid (TSS) (Brix)}

Total soluble solid in tomato paste which was stored with different temperature and time presented in table 2. TSS of tomato paste was found to be constant at $50^{\circ} \mathrm{C}$ temperature for 60 days of preservation while it was slightly decreased at $75^{\circ} \mathrm{C}$ and $100^{\circ}$ Ctemperatures from the period of 30-60days.This result agrees with Nwanekezi ${ }^{[22]}$, who reported the total soluble solid of tomato pulp was decreased with storage temperature. Decrease in TSS was more in tomato pulp samples stored at higher temperature $\left(25^{\circ} \mathrm{C}\right)$ than at lower temperature $\left(-10^{\circ} \mathrm{C}\right)$. The reason for this could be attributed to the higher storage temperature of the ones outside which could have led to increase in rate of spoilage, the bacteria (Bacillus thermoacidurans) probably being able to flourish better at this temperature. Another cause for the decrease could also be that the solids are probably broken down during storage. This observation agree with Ibironke and Rotimi ${ }^{[23]}$, who observed that with the storage time the rate of TSS of tomato powder was decreased outside greater than those in the fridge.

\section{Determination of beta-carotene content}

The amount of beta-carotene was determined at different temperature and time as shown in table 3. Decreased of beta carotene was observed through the storage period. The amount of beta-carotene was found to be constant up to $50^{\circ} \mathrm{C}$ temperature for 20days of time period. Above this temperature and time slightly decreasing the concentration of betacarotene was observed. The prominent decrease in concentration of beta-carotene was found at $75^{\circ} \mathrm{C}$ and $100^{\circ} \mathrm{C}$ temperature. Variation of loss of beta carotene might be due to various temperature and time. At lower temperature retained the beta-carotene for long time as compared to higher temperature storage conditions.

\section{Determination of ascorbic acid content}

The amount of ascorbic was determined at different temperature and time as shown in table 4. Decreased in ascorbic content was observed during storage of tomato paste at different temperatures. The amount of ascorbic was found to be constant up to $50^{\circ} \mathrm{C}$ temperature for 10days of time period. Above this temperature and time slightly decreasing the concentration of ascorbic was observed. The prominent decrease in concentration of beta-carotene was found at $50^{\circ} \mathrm{C}, 75^{\circ} \mathrm{C}$ and $100^{\circ} \mathrm{C}$ temperature. The cause of decrease in ascorbic acid at higher temperature is due to oxidation which is greater at higher temperature. According to Smith and Hull ${ }^{[24]}$ increased temperature normally results in high percentage loss of ascorbic acid.

\section{Determination of titratable acidity}

The percentage of acidity was determined at different temperature and time as shown in 
table 5. Increasing in acidity was observed during storage of tomato paste at different temperatures.

The amount of acidity was found to be constant up to $25^{\circ} \mathrm{C}$ temperature for 60days of time period. Above this temperature and time slightly increasing the amount of acidity was observed. The prominent increasing in amount of acidity was found at $50^{\circ} \mathrm{C}, 75^{\circ} \mathrm{C}$ and $100^{\circ} \mathrm{C}$ temperature. For all samples through the storage period, the titratable acidity was increased. Acidity was increased at increasing temperature. It may also be due to oxidation of alcohol and aldehyde during processing and is influenced by storage temperature, higher the temperature greater the increase in acidity, this is a similar to result of previous study ${ }^{[25]}$.

On the basis of results we concluded that tomato paste for ready to use could be prepared by drying process. The decreasing the level of lycopene, TSS, beta-carotene and ascorbic acid with increasing temperature indicates that, lower and ambient temperatures are useful for storage of tomato paste for long period while higher temperature deteriorate the tomato paste.

Decreasing concentration of lycopene, betacarotene and ascorbic acid with increasing temperature suggests that nutritional value of tomato paste could be prevented by using low temperature during storage condition. Developed procedure for tomato paste preparation by vacuum drier could be utilized for commercial value in food processing industries.

\section{References}

1. Rahman MJ, Talukder MAI, Hossain MF, Mahomud MS, Islam MA, Shamsuzzoha M. Detection of Cryptosporidium oocysts in Commonly Consumed Fresh Salad
Vegetables. American Journal of Microbiological Research. 2014; 2(6): 224-226. https://doi: 10.12691/ajmr-2-69.

2. Noor F, Rahman MJ, Mahomud MS, Akter MS, Md. Aminul Islam Talukder MAI, Ahmed M. Physicochemical Properties of Flour and Extraction of Starch from Jackfruit Seed. International Journal of Nutrition and Food Sciences. 2014; 3(4): 347-354. doi: 10.11648/j.ijnfs.20140304.27.

3. Azad AKM, Ali MA, Akter MS, RahmanMJ, Maruf AM. Isolation and Characterization of Pectin Extracted from Lemon Pomace during Ripening. Journal of Food and Nutrition Sciences. 2014; 2(2): 30-35. doi: 10.11648/j.jfns.20140202.12.

4. Guil-Guerrero JL, Rebolloso-Fuentes MM. Nutrient composition and antioxidant activity of eight tomato (Lycopersicon esculentum) varieties. Journal of Food Composition and Analysis. 2009; 22: 123129.https://doi.org/10.1016/j.jfca.2008.10 .012

5. Martinez VI, Periago MJ, Provan G, Chesson A. Phenolic compounds, lycopene and antioxidant activity in commercial varieties of tomato (Lycopersicon esculentum). Journal of Agricultural and Food Chemistry. 2002; 82: 323-330. https://doi.org/10.1002/jsfa.1035

6. Periago MJ, Garcia-Alonso FJ, Jacob K, Olivares AB, Bernal MJ, Iniesta MD et al. Bioactive compound folates and antioxidant properties of tomatoes (Lycopersicon esculentum) during vine ripening. International Journal of Food Science and Nutrition. 2008; 12:1-15.doi: 10.3109/09637480701833457

7. Asaduzzaman M, Haque ME, Rahman MJ, Hasan SMK, Ali MA, Akter MS, Ahmed M. Comparisons of 
physiochemical, total phenol, flavanoid content and functional properties in six cultivars of aromatic rice in Bangladesh. African journal of Food Science, 2013; 7(8): $\quad 198-203 . \quad$ DOI: 10.5897/AJFS2013.1001.

8. Sesso HD, Buring JE, Norkus EP, Gaziano JM. Plasma lycopene, other carotenoids, and retinol and the risk of cardiovascular disease in women. American Journal of Clinical Nutrition, 2004; 79: 47-53. DOI:10.1093/ajcn/79.1.47

9. Walfisch $S$, Walfisch $Y$, Kirilov E, Linde $\mathrm{N}$, Mnitentag H, Agbaria R et al. Tomato lycopene extract supplementation decrease insulin like growth factor 1 levels in colon cancer patients. European Journal of Cancer Prevention, 2007; 16(4): 298-303. DOI:10.1097/01.cej.0000236251.09232.7 b

10. Willcox JK, Catigani GL, La Zarus S. Tomatoes and cardiovascular health. Critical Review in Food Science and Nutrition, 2003; 43:1-18. DOI:10.1080/10408690390826437.

11. Gould WA. In tomato production, processing and technology 3rd Edition. Baltimore, MD: CT Publications, 1992. ttps://www.sciencedirect.com/science/boo k/9781845695996.

12. Mahomud M.S., Ali, M.K., Rahman, M.M., Rahman, M.H., Sharmin, T., and Rahman, M.J. Effect of Honey and Sugar Solution on the Shelf Life and Quality of Dried Banana (Musa paradisiaca) Slices. American Journal of Food Science and Technology. 2015; 3(3): 60-66. https://doi: 10.12691/ajfst-3-3-2.

13. Raab CA. Canning Tomatoes and Tomato Products. A Pacific Northwest Extension Publication, Oregon state University, Washington.2010, 3-14. https:///C:/Users/Balaji/Downloads/pnw3 00.pdf
14. Eze JI. Studies on the effect of different solar driers on the vitamin content of tomato (Solanum lycopersicon). Journal of Food Processing Technology. 2012; 3:9 https://doi.org/10.1063/1.4763563

15. Safdar MM, Amer M, Muhammad A, Nouman S, Tabassum H. Development and quality characteristics studies of tomato paste stored at different temperatures. Pakistan Journal of Nutrition. 2010; 9(3): 265-268. http://pjbs.org/pjnonline/fin1632.pdf

16. Nwanekezi EC, Onyyali NO. Effect of chemical preservation on the shelf life of bottled intermediate moisture tomato paste stored at ambient temperature. Nigerian Food Journal. 2005; 23: 01897241.

http://dx.doi.org/10.4314/nifoj.v23i1.336 16

17. Hossain MN, Fakruddin M, Islam MN. Effect of chemical additives on the shelf life of tomato juice. American Journal of Food Technology.2011; 6(10): 914-923. DOI:10.3923/AIFT. 2011.914.923.

18. Grolier P, Bartholin G, Broers L, CarisVeyrat C, Dadomo M, Di Lucca G, Dumas Y, Meddeens F, Sandei L, Schuch W. Les anti-oxydants de la tomate et leurbiosynthèse In : Les anti- oxydants de la tomateetses derives et leurbienfaits pour la santé. Le livreblane de la tomate, Action concertée de la Commission Eurpéenne, FAIR CT, 2000; 97-32333. https://prodinra.inra.fr/record/54632.

19. Srivastava RR, Kumar S. Important methods for analysis of fruits / vegetables and their products. Fruit and Vegetable preservation Principles and Practices 2nd Edition, 1993; 321-339. http://old.fssai.gov.in/Portals/0/Pdf/Manu al_Fruits_Veg_25_05_2016.pdf

20. Ranganna S. Handbook of Analysis and Quality Control for Fruit and Vegetable Products. 2nd Edition. Tata McGraw Hill Publishing Company Limited., New 
Delhi,

1991.https://books.google.co.in/books/ab out/Handbook of Analysis and Quality Control.html?id=jQN8Kpj0UOMC

21. Trifiro AS, Gherardi C,oni Z, ZanottiA, PistocchiM,Paciello G, Sommi F, ArelliPL, Anteguena MAM. Quality changes in tomato concentrate production: Effects of heat treatment. Industrial Conserve. 1998; 73(1): 30-41.

22. Nwanekezi EC, OnyyaliNO. Effect of chemical preservation on the shelf life of bottled intermediate moisture tomato paste stored at ambient temperature. Nigerian Food Journal, 2005. 23: 01897241. http://agris.fao.org/agrissearch/search.do?record $\mathrm{ID}=\mathrm{AJ} 2013001565$

23. Ibironke A, Rotimi A. Oderinde. Effects of different home storage conditions and preservation on some chemical constituents of tomato (Lycopersicon esculentum). Journal of Applied Chemistry, 2013; $\quad$ (4)1929.http://www.iosrjournals.org/iosrjac/papers/vol4-issue4/E0441929.pdf

24. Smith JS, Hull YH. Food Processing Principles and Applications. Blackwell Publishing Company, USA, 2004.https://www.scribd.com/doc/586375 16/Food-Processing-Principles-andApplications-Smith-2004

25. Gould WA. In tomato production, processing and technology 3rd Edition. Baltimore, MD: CT Publications, 1992.https://www.amazon.com/TomatoProduction-Processing-TechnologyGould/dp/1845695992

\section{How to cite this article:}

Sweta Singh, Baljor Singh, Ajay Kumar Singh, Kunal Singh and Vinay Kumar Pandey. 2020. Preparation and Effect of Different Temperature and Time on Nutritional Quality of Tomato Paste. Int.J.Curr.Microbiol.App.Sci. 9(11): 1144-1151. doi: https://doi.org/10.20546/ijcmas.2020.911.133 